\title{
COMPARATIVE ANALYSIS OF THE 1-MILE RUN TEST EVALUATION FORMULAE: ASSESSMENT OF AEROBIC CAPACITY IN MALE LAW ENFORCEMENT OFFICERS AGED 20-23 YEARS
}

\author{
GÜRHAN KAYIHAN ${ }^{1,2}$, ALI ÖZKAN 3 , YUSUF KÖKL ̈̈ ${ }^{4}$ ENDER EYUBOĞLU ${ }^{5}$, FIRAT AKÇA ${ }^{6}$, \\ MITAT KOZ ${ }^{6}$, and GÜLFEM ERSÖZ ${ }^{6}$
}

${ }^{1}$ Personal Nutrition Training Center, Ankara, Turkey

Physical Fitness Department

${ }^{2}$ Unaffiliated researcher, Oxford, UK

${ }^{3}$ Bartın University, Bartın, Turkey

School of Physical Education and Sports

${ }^{4}$ Pamukkale University, Denizli, Turkey

School of Sport Sciences and Technology

${ }^{5}$ Nebahat Taşkın Primary School, Ankara, Turkey

${ }^{6}$ Ankara University, Ankara, Turkey

Sport Sciences Faculty

\begin{abstract}
Objectives: The purpose of this study was to compare values of aerobic performance in the 1-mile run test (1-MRT) using different formulae. Material and Methods: Aerobic capacities of 351 male volunteers working for the Turkish National Police within the age range of 20-23 years were evaluated by the 1-MRT and the 20-metre shuttle run (20-MST). VO values were estimated by the prediction equations developed by George et al. (1993), Cureton et al. (1995) and Kline et al. (1987) for the 1-MRT and by Leger and Lambert (1982) for the 20-MST. Results: The difference between the results of the different formulae was significant $(\mathrm{p}=0.000)$. The correlation coefficient between the estimated $\mathrm{VO}_{2 \max }$ using Cureton's equation, George's equation, Kline's equation and the 20-MST were $0.691(\mathrm{p}<0.001), 0.486(\mathrm{p}<0.001)$ and 0.608 $(\mathrm{p}<0.001)$, respectively. The highest correlation coefficient was between the $\mathrm{VO}_{2 \max }$ estimated by the 20-MST and Cureton's equation. Similarly, the highest correlation coefficient $(\mathrm{r}=-0.779)$ was between the 1-mile run time and the $\mathrm{VO}_{2 \max }$ estimated by Cureton's equation. Conclusions: When analysing more vigorous exercise than sub-maximal exercise, we suggest that Cureton's equation be used to predict the $\mathrm{VO}_{2 \max }$ from 1-mile run/walk performance in large numbers of healthy individuals with high $\mathrm{VO}_{2 \max }$. This research compares the use of 3 different formulae to estimate $\mathrm{VO}_{2 \max }$ from 1-mile run/ walk performance in male law enforcement officers aged 20-23 years for the first time and reports the most accurate formula to use when evaluating aerobic capacities of large numbers of healthy individuals.
\end{abstract}

Key words:

Maximal oxygen uptake, Field aerobic tests, Police officers, One mile run test, Physical fitness, Young adults

Received: January 22, 2013. Accepted: December 31, 2013.

Corresponding author: G. Kayihan, Didcot, Oxfordshire, OX11 7UN, UK (e-mail: gkayihan@yahoo.com). 


\section{INTRODUCTION}

Since the duty of law enforcement is a high-risk profession, personnel have to endure adverse conditions that might arise from this risk, and have to expend very high physical effort when encountering crime [1-3]. Police officers have physically strenuous jobs and it is crucial for them to be in top physical health in order to perform their job to the best of their abilities. Therefore, policemen should be healthy with a high level of physical fitness [4,5].

Aerobic fitness (cardiorespiratory endurance) is one of the most important components of health-related physical fitness relating to the ability of the circulatory and respiratory systems to supply fuel during sustained physical activity and to eliminate fatigue products after supplying fuel. Aerobic capacity, measured by maximal oxygen uptake $\left(\mathrm{VO}_{2 \max }\right)$, is the "ability to perform large muscle, dynamic, moderate-tohigh intensity exercise for a prolonged period" [6-9].

Law enforcement agencies should implement programs that prepare officers to perform their jobs within their own genetic potential and in good health for the length of their careers [10]. Physical fitness has a direct impact on job performance. Based on job descriptions, a core list of physical tasks required to perform the duties of a law enforcement officer has been identified. These tasks are: running, climbing, jumping, lifting/carrying, dragging, pushing, and the use of force [11]. The majority of police departments test police candidates' physical fitness. Test batteries consist of the events that require from the candidates to perform simulations of important tasks that are part of a police officer's job. Body composition, strength, aerobic fitness (endurance) and coordination are required in these events. In addition, a physical agility test must be passed by all candidates [12,13]. A specific aerobic capacity is necessary for a police officer to perform these physical requirements adequately. Therefore, aerobic capacity of police officers is also tested. Studies have shown that there is a statistically high correlation between high aerobic capacity and arrests [14]. Fitness programming for the law enforcement officers should focus on improving aerobic fitness [15]. The aerobic capacity standard is job related and consistent with business necessity, and there is an "obvious relationship between aerobic capacity and the critical and important duties of a police officer" $[14,16]$. Law enforcement officers who remain physically fit prove more readily able to cope with the day-to-day stress of the job and are better prepared to handle critical incidents [17]. Cardiovascular endurance is necessary in approximately $11 \%$ of foot pursuits and over $50 \%$ of the use of force encounters [18].

The importance of testing $\mathrm{VO}_{2 \max }$ is becoming increasingly recognized in the assessment of fitness levels. Maximum oxygen intake $\left(\mathrm{VO}_{2 \max }\right)$ is considered one of the most valid parameters to evaluate cardio-respiratory capacity [8,19-21]. However, despite a high level of accuracy, direct measurement $\mathrm{VO}_{2 \max }$ tests are primarily reserved for the laboratory settings because of costly equipment, the need for trained technicians and the inability to test large numbers of people at one time [22]. It is also time consuming - the test requires about 30 minutes and only one person can be measured at a time. Therefore, the direct measurement of aerobic capacity is not possible or practical for most field settings, such as schools, police departments or armies where large numbers of people must be subjected to the test. The ability to track cardiovascular fitness $\left(\mathrm{VO}_{2 \max }, \mathrm{ml} \times \mathrm{kg}^{-1} \times \mathrm{min}^{-1}\right)$, and therefore, cardiovascular health status of large populations of school age youth and young adults using standard laboratory protocols is not feasible. To deal with these problems, a number of field tests have been developed to estimate cardiorespiratory fitness $[19,23,24]$. Running/walking based field tests are by far the most popular types of tests used to estimate cardiorespiratory fitness in both young people and in adults $[25,26]$. Such tests require the subject either to cover as much distance as possible in a set time [27] or to cover a set distance in the fastest time possible [28,29]. The 1-mile run [23,30-33]; 1.5-mile run/walk (MRW) and the Progressive Aerobic Cardiovascular Endurance Run [34-37] 
have been established as the most valid and reliable field tests when assessing cardiovascular fitness of school age youth and young adults. The 1-MRT and 20-MST estimate aerobic capacity from running performance as well as participant's characteristics such as age, gender, body weight, heart rate (HR) and the ratio of weight to height. Several equations have been developed to estimate the highest rate of oxygen uptake $\left(\mathrm{VO}_{2 \max }\right)$ and aerobic capacity from 1-mile run/walk time (1-MRWT) [21,22,30].

The Cooper Institute has worked with fitness programs in law enforcement, public and military safety since 1976 and it recommends the 1.5-MRT for police officers [38]. This fitness test has the validity to predict an officer's ability to perform essential and critical physically demanding tasks regardless of age, gender or handicap condition. The 1.5-MRT has also been found to be scientifically valid and defensible in court, as it is job related [38]. The 20-MST has been reported by the laboratory to provide estimates of $\mathrm{VO}_{2 \max }$ for the members of an active adult population. However, the objective of the present study was to assess the criterion related validity of the 1-MRT for estimating $\mathrm{VO}_{2 \max }$ in untrained healthy people. Although most of the police officers' and police candidates' aerobic capacities were tested by the 1-MRT, the extent to which these equations have criterion related validity in endurance-trained youth police with high aerobic capacity is unclear. No study has investigated the validity of the 1-MRT for male law enforcement officers aged between 20 and 23 years. Therefore, the purpose of this study was to compare the values of aerobic performance using 3 different formulae for the 1-MRT and the 20-MST for youth police.

\section{MATERIAL AND METHODS}

\section{Subjects}

In this study, 351 male volunteers working for the Turkish National Police within the age range of 20-23 years were investigated. The volunteers were endurance-trained youth police officers with high aerobic capacity. Before the volunteers were accepted to participate in this study, they were required to attend basic military training 5 times per week for 12 weeks. Major characteristics of the organized training consisted of 35\% aerobic endurance, $25 \%$ strength, $15 \%$ speed, $15 \%$ agility, $10 \%$ coordination and flexibility.

\section{Anthropometric measurements}

Height (to the nearest $0.01 \mathrm{~mm}$ ) and weight (to the nearest $0.1 \mathrm{~kg}$ ), without shoes, were measured in the case of each participant using a portable stadiometer (Holtain, UK) and physician's scale (Tanita TBF 401 A, Japan). Body mass index (BMI) was calculated using the formula: weight $(\mathrm{kg})$ divided by height $(\mathrm{m})$ squared [39].

\section{Aerobic Capacity Assessment}

The aerobic capacities of the policemen were evaluated by the 1-MRT and the 20-MST within a 2-week period. Aerobic capacities obtained from the 1-MRT were compared with aerobic capacities obtained from the 20-MST.

The participants were instructed and encouraged to complete the distance of one mile as quickly as possible. Because the rate of oxygen uptake is related in part to the pace sustained, it is possible to estimate the highest rate of oxygen uptake possible from the average pace sustained. Walking was permitted if the participant could not keep running. The tests were performed on a $400 \mathrm{~m}$ track laid out on the running field. Time needed to complete the test and the post-exercise HR was recorded immediately following the test. One week before the test, all the participants received comprehensive instructions about the test, after which they practised it once. All tests were conducted by the same investigators and at the same time of the day in the case of each participant [33]. Age, gender and body fatness also affect prediction of aerobic capacity. Therefore, aerobic capacity is predicted from 1-mile run time, age, gender and BMI using different equations. 
The equations of Cureton (equation 1) [30], Kline (equation 2) [21] and George (equation 3) [22] were used to predict $\mathrm{VO}_{2 \max }\left(\mathrm{ml} \times \mathrm{kg}^{-1} \times \mathrm{min}^{-1}\right)$ for the 1-MRT.

$$
\begin{gathered}
\mathrm{VO}_{2 \max }=0.21 \text { (agexgender) }-0.84(\mathrm{BMI})- \\
-8.41 \text { (time) }+0.34\left(\text { time }^{2}\right)+108.94 \\
\mathrm{VO}_{2 \max }=-0.3877(\text { age })+6.315 \text { (gender) }- \\
-0.0769 \text { (weight) }-3.2649(\text { time })- \\
-0.1565(\mathrm{bpm})+132.853 \\
\mathrm{VO}_{2 \max }=100.5+8.344 \text { (gender) }- \\
-0.1636 \text { (body mass) }-1.438 \text { (jog time) }- \\
-0.1928(\mathrm{bpm})
\end{gathered}
$$

The 20-MST is a multi-stage test published by Léger and Lambert [40] and revised in 1988 [34]. It involves running back and forth across a 20-metre course in time to music played from a tape or CD. Beeps on the sound track indicate when a person should reach the ends of the course. The test begins at a slow pace, and each minute the pace increases. The running speed increases by $0.14 \mathrm{~m} \times \mathrm{s}^{-1}$ each minute; this change in running speed is described as a change in the level. A participant continues running until the pace can no longer be maintained. If the line is not reached in time for each beep, the subject has to run to the line, turn and try to catch up with the pace within two more 'beeps'. In addition, if the line is reached before the beep sounds, the subject has to wait until the beep sounds. The test is stopped if the subject fails to reach the line (within $2 \mathrm{~m}$ ) for 2 consecutive ends.

The equation of Léger \& Lambert (equation 4) [40] was used for prediction of aerobic capacity from the 20-MST.

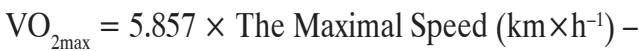

$$
\begin{aligned}
& -19.458
\end{aligned}
$$

\section{ETHICS}

This study was approved by The Research Ethics Committee of the Ankara University Medical Faculty and the Health Department of Turkish National Police. The authors confirm this study meet the guidelines of the Helsinki Declaration.

\section{STATISTICS}

Means and standard deviations are given as descriptive statistics. Differences between the groups were analysed using the student t-test for independent samples. The correlations between the results were made using Pearson's Correlation Analysis. For all statistics the significance level was set at $p<0.05$. Data were analysed using the Statistical Package for Social Sciences (SPSS) MS Windows Release 13.0.

\section{RESULTS}

Three hundred fifty one male volunteers working for the Turkish National Police within the age range of 20-23 years were investigated. Their mean age, height, body weight and BMI were $21.50 \pm 1.061$ years, $177.18 \pm 5.20 \mathrm{~cm}$, $69.51 \pm 7.08 \mathrm{~kg}$ and $22.11 \pm 1.95 \mathrm{~kg} / \mathrm{m}^{2}$ respectively. The mean estimated $\mathrm{VO}_{2 \max }\left(\mathrm{ml} \times \mathrm{kg}^{-1} \times \mathrm{min}^{-1}\right)$ and 1-MRWT (min) are presented in Table 1.

The correlation coefficient between the estimated $\mathrm{VO}_{2 \max }$ by the 20-MST $\left(\mathrm{ml} \times \mathrm{kg}^{-1} \times \mathrm{min}^{-1}\right)$ and the estimated $\mathrm{VO}_{2 \max }$ using Cureton's equation $(\mathrm{r}=-0.691$, $\mathrm{p}<0.001)$, Kline's equation $(\mathrm{r}=-0.608, \mathrm{p}<0.001)$ and George's equation $(r=-0.486, p<0.001)$ were significant (scattergrams shown in Figure 1, Figure 2 and Figure 3 respectively). The correlation coefficient between the 1-MRWT and the estimated $\mathrm{VO}_{2 \max }$ using $\mathrm{Cu}$ reton's equation ( $\mathrm{r}=-0.779, \mathrm{p}<0.001)$, Kline's equation $(\mathrm{r}=-0.617, \mathrm{p}<0.001)$ and George's equation $(\mathrm{r}=-0.332, \mathrm{p}<0.001)$ were significant (scattergrams shown in Figure 4, Figure 5 and Figure 6 respectively). The correlation coefficient between the HR at the end of the 1-MRT (bpm) and the $\mathrm{VO}_{2 \max }$ estimated by Kline's equation $(r=-0.502, p<0.001)$ and George's equation $(r=-0.734, p<0.001)$ were significant. There was no significant correlation between the HR at the end of the 1-MRT (bpm) and Cureton's equation $(\mathrm{r}=-0.002$, $\mathrm{p}>0.001)$. All correlation data are shown in Table 2. 
Table 1. The mean estimated $\mathrm{VO}_{2 \max }$ and 1-MRWT

\begin{tabular}{|c|c|}
\hline Variables & $\begin{array}{c}\text { Male }(\mathrm{N}=351) \\
\mathrm{M} \pm \mathrm{SD}\end{array}$ \\
\hline 1-MRWT (min) & $5.44 \pm 0.39$ \\
\hline Estimated $\mathrm{VO}_{2 \max }$ by 1-MRT (Cureton equation) $\left(\mathrm{ml} \times \mathrm{kg}^{-1} \times \mathrm{min}^{-1}\right)$ & $59.23 \pm 2.55$ \\
\hline Estimated $\mathrm{VO}_{2 \max }$ by 1-MRT (Kline equation) $\left(\mathrm{ml} \times \mathrm{kg}^{-1} \times \mathrm{min}^{-1}\right)$ & $70.99 \pm 2.22$ \\
\hline Estimated $\mathrm{VO}_{2 \max }$ by 1-MRT (George equation) $\left(\mathrm{ml} \times \mathrm{kg}^{-1} \times \mathrm{min}^{-1}\right)$ & $52.32 \pm 1.98$ \\
\hline Estimated $\mathrm{VO}_{2 \max }$ by the 20 -MST (Leger equation) $\left(\mathrm{ml} \times \mathrm{kg}^{-1} \times \mathrm{min}^{-1}\right)$ & $62.05 \pm 4.26$ \\
\hline
\end{tabular}

$\mathrm{VO}_{2 \max }$ - maximal oxygen uptake.

1-MRWT -1-mile run walk time.

M - mean; SD - standard deviation.

Table 2. Correlation between 1-MRWT, estimated $\mathrm{VO}_{2 \max }$ by the 20-MST, HR at the end of the 1-MRT and estimated $\mathrm{VO}_{2 \max }$ using different equations

\begin{tabular}{|c|c|c|c|}
\hline \multirow{2}{*}{ Variables } & \multicolumn{3}{|c|}{$\begin{array}{l}\text { Estimated } \mathrm{VO}_{2 \max } \text { by the 1-MRT } \\
\qquad\left(\mathrm{ml} \times \mathrm{kg}^{-1} \times \mathrm{min}^{-1}\right)\end{array}$} \\
\hline & $\begin{array}{l}\text { Cureton's } \\
\text { equation }\end{array}$ & $\begin{array}{l}\text { Kline's } \\
\text { equation }\end{array}$ & $\begin{array}{l}\text { George's } \\
\text { equation }\end{array}$ \\
\hline 1-MRWT (min) & $-0.779^{* *}$ & $-0.617^{* *}$ & $-0.332^{* *}$ \\
\hline Estimated $\mathrm{VO}_{2 \max }$ by the $20-\mathrm{MST}\left(\mathrm{ml} \times \mathrm{kg}^{-1} \times \mathrm{min}^{-1}\right)$ & $0.691^{* *}$ & $0.608^{* *}$ & $0.486^{* *}$ \\
\hline HR at the end of the 1-MRT (bpm) & -0.002 & $0.502^{* *}$ & $-0.734^{* *}$ \\
\hline
\end{tabular}

HR - heart rate. Other abbreviations as in Table 1.

** Correlation is significant at the 0.01 level (2-tailed).

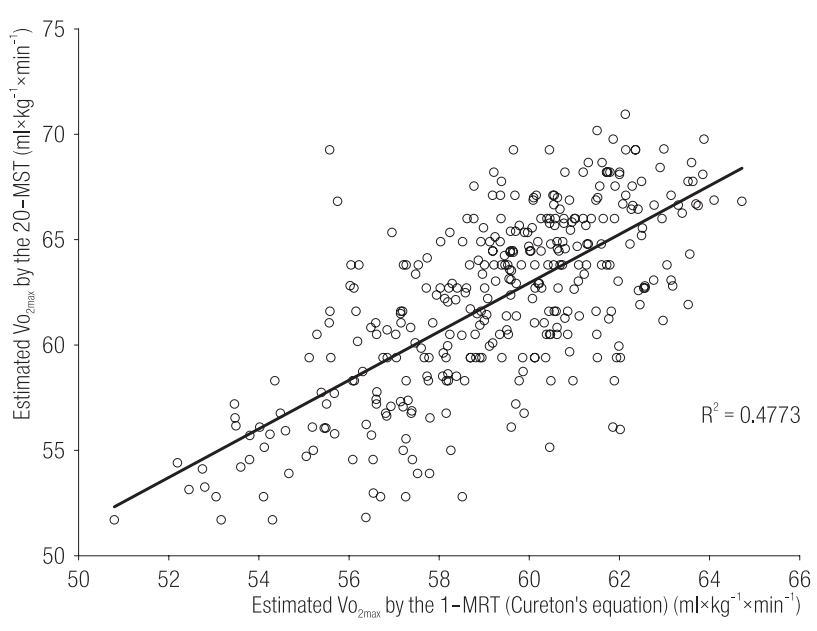

Fig. 1. Scattergrams of the estimated $\mathrm{VO}_{2 \max }$ using the 1-MRT equation from Cureton et al. [30] vs. the estimated $\mathrm{VO}_{2 \max }$ using the 20-MST equation from Leger and Lambert [40]

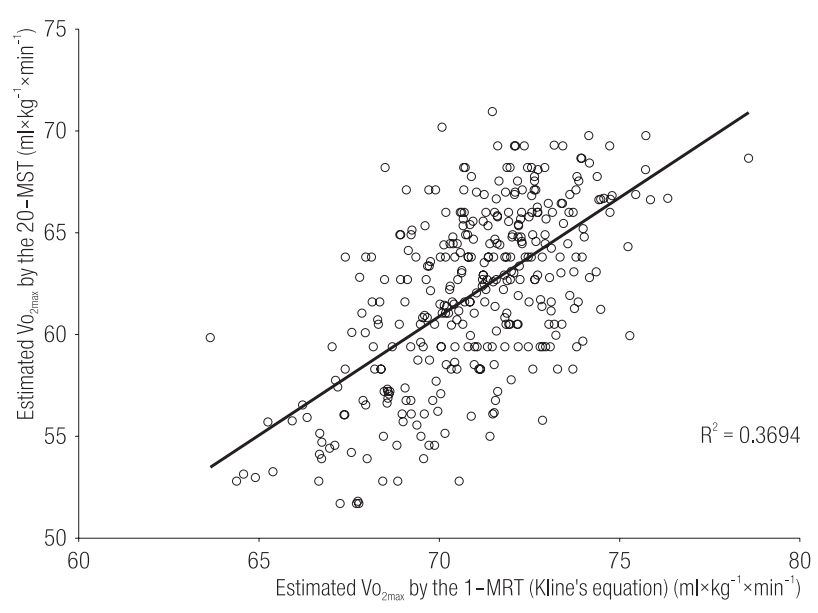

Fig. 2. Scattergrams of the estimated $\mathrm{VO}_{2 \text { mar }}$ by the 1-MRT equation from Kline et al. [21] vs. the estimated $\mathrm{VO}_{2 \max }$ by the 20-MST equation from Leger and Lambert [40] 




Fig. 3. Scattergrams of the estimated $\mathrm{VO}_{2 \max }$ by the 1-MRT equation from George et al. [22] vs. the estimated $\mathrm{VO}_{2 \max }$ by the 20-MST equation from Leger and Lambert [40]

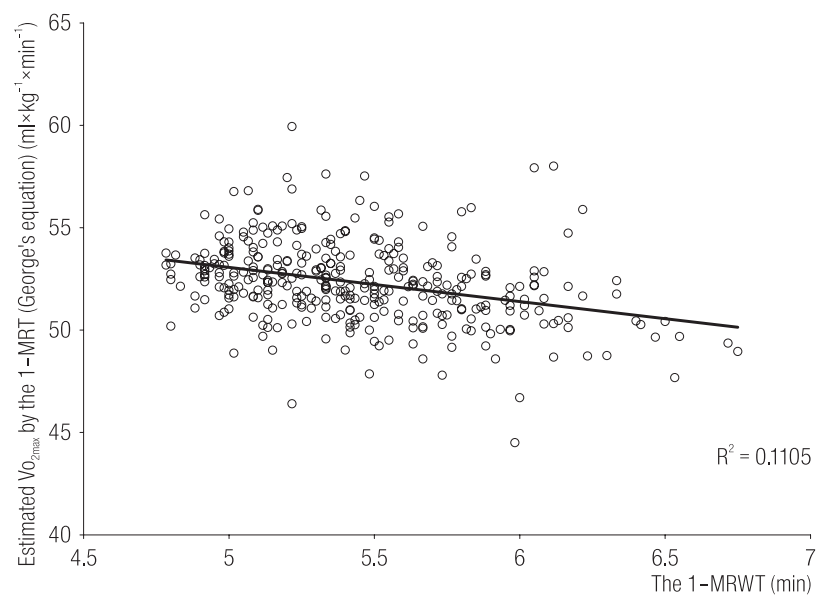

Fig. 5. Scattergram showing the relationship between the 1-mile run/walk time (1-MRWT) and the estimated $\mathrm{VO}_{2 \max }$ by 1-MRT (George's equation) in male law enforcement officers aged $20-23$ years

\section{DISCUSSION}

The 1-MRT and the 20-MST are reliable and valid methods of testing aerobic performance. They have been used for assessment of aerobic capacity in different disciplines and for all ages and genders. In the studies concerning the 20-MST, the tests were mostly performed indoors, on a $20 \mathrm{~m}$ track [35]. However, weather and surface conditions must be considered. The 20-MST and the Timed

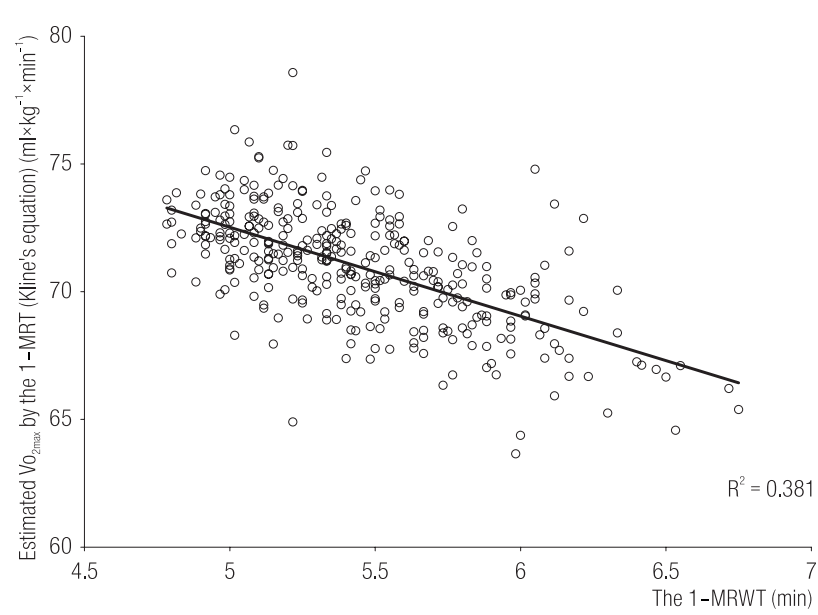

Fig. 4. Scattergram showing the relationship between the 1-mile run/walk time (1-MRWT) and the estimated $\mathrm{VO}_{2 \max }$ by 1-MRT (Kline's equation) in male law enforcement officers aged 20-23 years

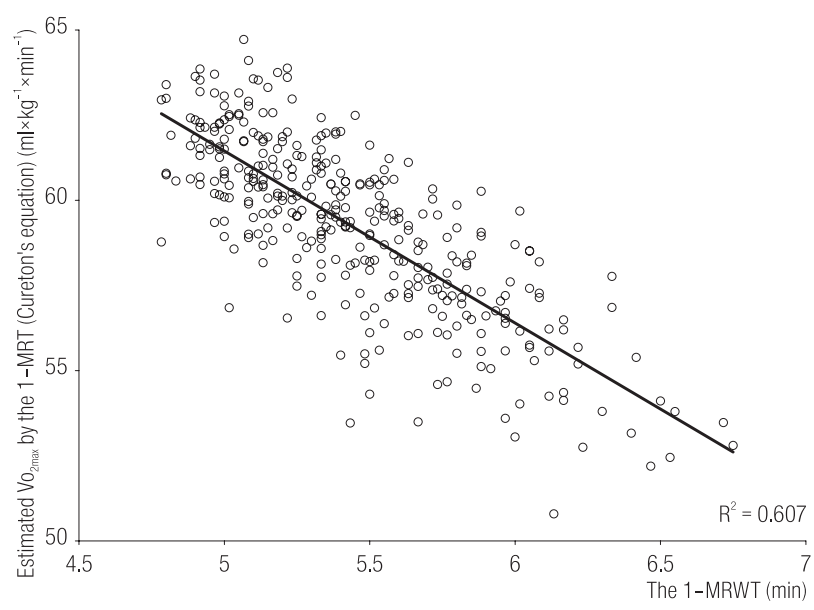

Fig. 6. Scattergram showing the relationship between 1-mile run/walk time (1-MRWT) and the estimated $\mathrm{VO}_{2 \max }$ by 1-MRT (Cureton equation) in male law enforcement officers aged 20-23 years

Distance Runs are assumed to be relatively easy to administer, with no special qualifications required. One aspect that needs extra experience is the measurement of anthropometric data, which is performed in most studies [23,30,35-37,41-44]. The 20-MST is recommended officially in Japan by the Ministry of Education, Culture, Sports, Science and Technology (MEXT) to assess cardiovascular fitness in middle-aged adults [45]. George's, 
Cureton's and Kline's equations for the 1-MRT require a little more expertise due to the recording of anthropometric data as well as HR measurements, either manually or by using different measuring devices [22].

George's [22], Kline's [21] and Cureton's [30] equations were used to estimate the same parameter of $\mathrm{VO}_{2 \max }$ using the results of the 1-MRT. However, the difference between the results of the 3 formulae was significant $(p=0.000)$ and the correlation coefficients obtained using the 3 formulae differ in our present study. In the view of our results, we suggest that the subjects should be evaluated using more than one equation to predict aerobic capacity. Prior to the 1-MRT or 1.5-MRT, subjects are instructed to "run as fast as possible" or "give maximum effort" and as a result untrained individuals may have difficulty running at a proper pace. Also, high intensity exercise has been associated with greater cardiovascular risk and orthopaedic injury to the foot, ankle and knee.

Kline et al. [21] and George et al. [22] developed a 1-MRT using the multiple linear regression analysis and employed elapsed walk time, exercise HR, age, gender and body mass as independent variables to predict $\mathrm{VO}_{2 \max }$ for sedentary or untrained individuals. Based on their results, the 1-MRT appears relatively accurate, safe and convenient. The elapsed run time criterion ( $\geq 8 \mathrm{~min}$ for males) and exercise HR limit ( $\leq 180 \mathrm{bpm}$ ) utilized for the 1-mile run were based on typical energy costs and age specific HR data involving running activity [22]. In previous studies, the mean values for run time $9.4 \pm 1.3 \mathrm{~min}[22] ; 13.30 \pm 1.35 \mathrm{~min}$ [21] and $\mathrm{HR}$ at the end of the test $169.00 \pm 5.9 \mathrm{bpm}$ [22]; $175.4 \pm 6.7 \mathrm{bpm}$ [21] in the subjects were determined. In our present study, the mean values for run time of our subjects $(5.44 \pm 0.39$ min) was determined to be shorter and the HR at the end of the test $(193.58 \pm 7.97 \mathrm{bpm})$ was higher than in the case of Kline et al. [21] and George et al. [22]. Although Weiglein et al (2011) [46] demonstrated that the 1-MRT using the equation of Kline et al. [21] to predict $\mathrm{VO}_{2 \max }$ is a valid predictor of aerobic capacity and also can be suggested as an alternative to the 1.5-MRT in assessing cardiovascular fitness of U.S Air Force males in active duty, our study has shown that the 1-MRT using Kline's equation may overestimate $\mathrm{VO}_{2 \max }$ by $14 \%$ according to our 20-MST results (Table 1).

Similarly, Dolgener et al (1994) and George et al (1998) have shown that the equation of Kline et al. may overestimate the $\mathrm{VO}_{2 \max }$ in civilians under the age of 40 years by as much as $23 \%[47,48]$. The over-prediction of $\mathrm{VO}_{2 \max }$ using Kline's equation in the aforementioned studies was likely due to the shorter run time. Our subjects' run time $(5.44 \pm 0.39 \mathrm{~min})$ is by nearly 8 minutes shorter than Kline's subjects $(13.30 \pm 1.35 \mathrm{~min})$. On the other hand, George's equation underestimates $\mathrm{VO}_{2 \max }$ by approximately $16 \%$ according to the 20-MST results. This can be explained by the higher HR. In George's equation, HR has a negative effect on the estimated $\mathrm{VO}_{2 \max }$. In George's study, the subjects finish the 1-MRT in $9.4 \pm 1.3$ minutes with a HR of $169.00 \pm 5.9 \mathrm{bpm}$. Our subjects' run time is nearly 2 times shorter than George's subjects' time. As a result of fast running, our subjects' exertion $(193.58 \pm 7.97 \mathrm{bpm})$ was higher than George's subjects' (169.00 \pm 5.9 bpm). Due to the impact of HR in the equation, the lowest correlation coefficient $(\mathrm{r}=-0.332)$ was found between the 1-mile run time and the $\mathrm{VO}_{2 \max }$ evaluated by George's 1-MRT equation (Table 2).

Inclusion of the HR measurement may jeopardize validity of the test. Therefore, the tests where no pulse is recorded are preferred over the tests where HR is required for the estimation of $\mathrm{VO}_{2 \max }$. Day to day variances in heartbeat due to, among other reasons, stress, tiredness, or illness make the reliability of these measurements questionable. In the study of Boreham et al. [36] the linear relationship that existed between heartbeat and oxygen consumption might have been influenced by emotional factors giving a less reliable result. To illustrate this effect, Cureton's equation was used to predict $\mathrm{VO}_{2 \max }\left(\mathrm{ml} \times \mathrm{kg}^{-1} \times \mathrm{min}^{-1}\right)$ for the 1-MRT in our study. After eliminating the HR effect, 
the highest correlation coefficient $(\mathrm{r}=0.691)$ was found between the estimated $\mathrm{VO}_{2 \max }$ evaluated by the 20-MST and the estimated $\mathrm{VO}_{2 \max }$ evaluated by Cureton's 1-MRT equation. In contrast, the lowest correlation coefficient $(\mathrm{r}=0.486)$ was found between the estimated $\mathrm{VO}_{2 \max }$ evaluated by the 20 -MST and the estimated $\mathrm{VO}_{2 \max }$ evaluated by George's 1-MRT equation due the influence of $\mathrm{HR}$ in the equation.

In summary, when analysing more vigorous exercise than sub-maximal exercise over a short duration, we conclude that Cureton's equation provides valid estimates of $\mathrm{VO}_{2 \max }$ from 1-mile run/walk performance in young police officers. Furthermore, we suggest that George's equation cannot be used instead of Cureton's and Kline's equations in males aged between 20 and 23 years whose $\mathrm{HR}$ at the end of the test is high ( $\geq 180 \mathrm{bpm}$ ). The main finding of this study is that George's equation underestimates aerobic capacity in endurance-trained youth police officers with high $\mathrm{VO}_{2 \max }$. The police volunteers in this study can also be thought of as healthy young adults with high aerobic capacity, therefore, this conclusion can be extended to cover physically fit young individuals.

\section{ACKNOWLEDGEMENTS}

The authors would like to extend their thanks to Dr. Melanie Smith for editing the language of the manuscript and to the law enforcement officers for their willingness to participate in the study.

\section{REFERENCES}

1. Sztajnkrycer MD, Callaway DW, Baez AA. Police officer response to the injured officer: A survey-based analysis of medical care decisions. Prehosp Dis Med. 2007;22(4):335-41.

2. Vrij A, Dingemans L. Physical effort of police officers as a determinant of their behavior toward criminals. J Soc Psychol. 1996;136(4):461-8, http://dx.doi.org/10.1080/00224545. 1996.9714027.
3. Vrij A, van der Steen J, Koppelaar L. The effects of physical effort on police officers' perception and aggression in simulated shooting incidents. Psychol Crime Law. 1994;1(4): 301-8, http://dx.doi.org/10.1080/10683169508411967.

4. Richard K. Justifying and Validating a Department Fitness Program. NLETA Online Magazine. 2003 [cited 2012 Dec 15]. Available from: http://www.nleta.com/articles/justifyingandvalidatingdeptfitnessprogram.html.

5. Suminski LT. Physical fitness and law enforcement. Roseville Police Department, Eastern Michigan University; 2006.

6. Taylor WC, Blair SN, Cummings SS, Wun CC, Malina RM. Childhood and adolescent physical activity patterns and adult physical activity. Med Sci Sports Exercise. 1999;31(1):118-23, http://dx.doi.org/10.1097/00005768-199901000-00019.

7. Mitchell JH, Sproule BJ, Chapman CB. The physiological meaning of the maximal oxygen intake test. J Clin Inves. 1958;37(4):538, http://dx.doi.org/10.1172/JCI103636.

8. Cureton K, Plowman S. Aerobic capacity assessments. In: Gregory J, James R, Harold B, editors. Fitnessgram reference guide. Dallas, TX: The Cooper Institute; 2008. p. 66-86.

9. Gordon NF. ACSM's guidelines for exercise testing and prescription. Philadelphia: Lippincott Williams \& Wilkins; 2009.

10. Shell DE. Physical fitness: Tips for the law enforcement executive. FBI Law Enforc Bull. 2005;74(5):27-31.

11. Quigley A. Fit for duty? The need for physical fitness programs for law enforcement officers. Police Chief. 2008;75(6):62.

12. Quigley A. Physical fitness and wellness at the Hallandale Beach Police Department. SLP Research. 2009;13(1):1-13.

13. McCormack W. Grooming and weight standards for law enforcement: The Legal Issues. FBI Law Enforc Bull. 1994;63(7):27-32.

14. Brooks ME, Agent JDSS, Unit LI. Law enforcement physical fitness standards and title VII. FBI Law Enforc Bull. 2001;70(5):26-31.

15. Pryor RR, Colburn D, Crill MT, Hostler DP, Suyama J. Fitness characteristics of a suburban special weapons and tactics team. J Strength Condit Res. 2012;26(3):752-7, http:// dx.doi.org/10.1519/JSC.0b013e318225f177. 
16. Mier CM, Gibson AL. Evaluation of a treadmill test for predicting the aerobic capacity of firefighters. Occup Med. 2004;54(6):373-8, http://dx.doi.org/10.1093/occmed/ kqh008.

17. Ebling P. Physical fitness in law enforcement. FBI Law Enforc Bull. 2002;71(10):1-7.

18. Smith Jr J. Health and fitness in law enforcement: A voluntary model program response to a critical issue. CALEA Iss. 2005;14:87.

19. Akerholt M, Jacobsen T, Holm S, Nordbo C. The best indirect $\mathrm{VO}_{2 \max }$ test to be used at "Medisch Trainings Centrum" Geldrop when testing youth (age 12-18). Eindhoven: Fontys University of Professional Education Department of Physiotherapy; 2003.

20. Meredith MD, Welk GJ. Fitnessgram/Activitygram test administration manual. Dallas: Human Kinetics; 2006.

21. Kline GM, Porcari JP, Hintermeister R, Freedson PS, Ward A, McCarron RF, et al. Estimation of $\mathrm{VO}_{2 \max }$ from a one-mile track walk, gender, age, and body weight. Med Sci Sports Exerc. 1987;19(3):253-9.

22. George JD, Vehrs P, Allsen PE, Fellingham GW, Fisher AG. $\mathrm{VO}_{2 \max }$ estimation from a submaximal 1-mile track jog for fit college-age individuals. Med Sci Sports Exerc. 1993;25:401-6.

23. Buono MJ, Roby JJ, Micale F, Sallis JF, Shephard E. Validity and reliability of predicting maximum oxygen uptake via field tests in children and adolescents. Pediatr Exerc Sci. 1991;3(3):250-5.

24. McMurray RG, Harrell JS, Bradley CB, Deng S, Bangdiwala SI. Predicted maximal aerobic power in youth is related to age, gender, and ethnicity. Med Sci Sports Exerc. 2002;34(1):145-51, http://dx.doi.org/10.1097/00005768200201000-00022.

25. Castro-Piñero J, Ortega F, Mora J, Sjostrom M, Ruiz J. Criterion related validity of $1 / 2$ mile run-walk test for estimating $\mathrm{VO}_{2 \text { peak }}$ in children aged 6-17 years. Int J Sports Med. 2009;30(5):366-71, http://dx.doi.org/10.1055/s-00281105934.
26. Laukkanen R, Kukkonen-Harjula T, Oja P, Pasanen M, Vuori I. Prediction of change in maximal aerobic power by the 2-km walk test after walking training in middle-aged adults. Int J of Sports Med. 2000;21(2):113-6, http://dx.doi. org/10.1055/s-2000-8872.

27. Cooper KH. The new aerobics. New York: Bantam; 1970.

28. Getchell LH, Kirkendall D, Robbins G. Prediction of maximal oxygen uptake in young adult women joggers. Res Q. 1977;48(1):61-7, http://dx.doi.org/10.1080/10671315. 1977.10762151.

29. Ramsbottom R, Nute M, Williams C. Determinants of five kilometre running performance in active men and women. Brit J Sports Med. 1987;21(2):9-13, http://dx.doi. org/10.1136/bjsm.21.2.9.

30. Cureton K, Sloniger MA, O’Bannon JP, Black DM, McCormack WP. A generalized equation for prediction of $\mathrm{VO}_{\text {2peak }}$ from 1-mile run/walk performance. Med Sci Sports Exerc. 1995;27(3):445-51.

31. Cureton KJ, Baumgartner T, McManis BG. Adjustment of 1-mile run/walk test scores for skinfold thickness in youth. Pediatr Exerc Sci. 1991;3(2):152-67.

32. Cureton KJ. Determinants of distance running performance in children: analysis of a path model. Res Quart. 1977;48(2):270-9.

33. Plowman SA, Liu NYS. Norm-referenced and criterion-referenced validity of the one-mile run and PACER in college age individuals. Meas Phys Educ Exerc Sci. 1999;3(2):63-84, http://dx.doi.org/10.1207/s15327841mpee0302_1.

34. Léger LA, Mercier D, Gadoury C, Lambert J. The multistage 20 metre shuttle run test for aerobic fitness. J Sports Sci. 1988;6(2):93-101, http://dx.doi. org/10.1080/02640418808729800.

35. Barnett A, Chan L, Bruce I. A preliminary study of the 20-m multistage shuttle run as a predictor of Peak $\mathrm{VO}_{2}$ in Hong Kong Chinese students. Pediatr Exerc Sci. 1993;5(1):42-50.

36. Boreham C, Paliczka V, Nichols A. A comparison of the PWC170 and 20-MST tests of aerobic fitness in adolescent schoolchildren. J Sports Med Phys Fitness. 1990;30(1):19-23. 
37. Liu N, Plowman S, Looney M. The reliability and validity of the 20-meter shuttle test in American students 12 to 15 years old. Res Q Exerc Sport. 1992;63(4):360-5, http://dx.doi. org/10.1080/02701367.1992.10608757.

38. Cooper. Law Enforcement Fitness Specialists. Dallas: The Cooper Institute; 2002.

39. Gordon C, Chumlea W, Roche A. Stature, recumbent length, and weight. In: Lohman T, Roche A, Martorell R, editors. Anthropometric standardization reference manual. Champaign: Human Kinetics Books; 1988. p. 3-8.

40. Léger LA, Lambert J. A maximal multistage 20-m shutthe run test to predict $\mathrm{VO}_{2 \max }$. Eur J App Physiol Occup Physiol. 1982;49(1):1-12, http://dx.doi.org/10.1007/ BF00428958.

41. Massicotte D, Gauthier R, Markon P. Prediction of $\mathrm{VO}_{2 \max }$ from the running performance in children aged 10-17 years. J Sports Med Phys Fitness. 1985;25(1-2):10-7.

42. Macnaughton L, Croft R, Pennicott J, Long T. The 5 and 15 minute runs as predictors of aerobic capacity in high school students. J Sports Med Phys Fitness. 1990;30(1):24-8.

43. Maksud MG, Coutts KD. Application of the Cooper twelve-minute run-walk test to young males. Res Q.
1971;42(1):54-9, http://dx.doi.org/10.1080/10671188.1971. 10615035.

44. Pitetti K, Fernhall B, Figoni S. Comparing two regression formulas that predict $\mathrm{VO}_{2 \text { peak }}$ using the 20-m shuttle run for children and adolescents. Pediatr Exerc Sci. 2002;14(2): $125-34$.

45. Mikawa K, Yano Y, Senjyu H. Development of a Field Test for Evaluating Aerobic Fitness. Int $\mathrm{J}$ Sports Med. 2012;33(05):346-50, http://dx.doi.org/10.1055/s-0031 $-1301321$.

46. Weiglein L, Herrick J, Kirk S, Kirk EP. The 1-Mile walk test is a valid predictor of $\mathrm{VO}_{2 \max }$ and is a Reliable Alternative Fitness Test to the 1.5-Mile Run in US Air Force Males. Military Med. 2011;176(6):669-73.

47. Dolgener FA, Hensley LD, Marsh JJ, Fjelstul JK. Validation of the Rockport Fitness Walking Test in college males and females. Res Q Exerc Sport. 1994;65(2):152-8, http://dx.doi. org/10.1080/02701367.1994.10607610.

48. George JD, Fellingham GW, Fisher AG. A modified version of the Rockport fitness walking test for college men and women. Res Q Exerc Sport. 1998;69(2):205-9 http://dx.doi. org/10.1080/02701367.1998.10607685.

This work is available in Open Access model and licensed under a Creative Commons Attribution-NonCommercial 3.0 Poland License - http://creativecommons.org/ licenses/by-nc/3.0/pl/deed.en. 